\title{
Multidrug-resistant Escherichia coli and Salmonella spp. isolated from pigeons
}

\author{
Shah Jungy Ibna Karim¹,2(D), Mahfuzul Islam²,3(D), Tahmina Sikder ${ }^{4}$, Rubaya Rubaya5(D), Joyanta Halder ${ }^{5,6}$ (iD) and \\ Jahangir Alam ${ }^{5}$ iD
}

1. Department of Medicine and Public Health, Sher-e-Bangla Agricultural University, Dhaka 1207, Bangladesh;

2. Department of Microbiology and Parasitology, Sher-e-Bangla Agricultural University, Dhaka 1207, Bangladesh;

3. Ruminant Nutrition and Anaerobe Laboratory, Department of Animal Science and Technology, Sunchon National University, Suncheon 57922, South Korea; 4. Department of Pathology, Sher-e-Bangla Agricultural University, Dhaka 1207, Bangladesh; 5. Animal Biotechnology Division, National Institute of Biotechnology, Ganakbari, Ashulia, Savar, Dhaka 1349, Bangladesh; 6. Department of Biotechnology and Genetic Engineering, Islamic University, Kushtia 7003, Bangladesh.

Corresponding author: Jahangir Alam, e-mail: alamjahan2003@yahoo.com

Co-authors: SJIK: shahjungy@gmail.com, MI: mislam.micro.sau@gmail.com, TS: tahask.sau@gmail.com, RR: rubaiya.btge@gmail.com, JH: joybtge@gmail.com

Received: 20-05-2020, Accepted: 09-09-2020, Published online: 15-10-2020

doi: www.doi.org/10.14202/vetworld.2020.2156-2165 How to cite this article: Karim SJI, Islam M, Sikder T, Rubaya R, Halder J, Alam J (2020) Multidrug-resistant Escherichia coli and Salmonella spp. isolated from pigeons, Veterinary World, 13(10): 2156-2165.

\begin{abstract}
Background and Aim: Pigeon rearing has been gaining popularity for recent years. They are reared remarkably very close to the house of the owner. This activity, therefore, may pose potential threats for humans as well as other animals as pigeons may carry and spread different pathogens including drug-resistant bacteria. This study was conducted to explore the prevalence of Escherichia coli and Salmonella spp. as well as their antibiogram profile along with an association analysis.

Materials and Methods: Forty swab samples were collected from 20 pigeons during the study. E. coli and Salmonella spp. were isolated and identified on various types of agars, including MacConkey, Eosin methylene blue, Brilliant green, and Salmonella-Shigella agar. Biochemical tests such as the carbohydrate fermentation test, the triple sugar iron agar slant reaction, the indole test, the methyl red test, the catalase test, as well as the Voges-Proskauer test were also performed. Besides, the presence of $E$. coli was further confirmed by polymerase chain reaction (PCR). Moreover, antimicrobial susceptibility testing of the isolates was performed against nine antibiotics from seven classes on the Mueller-Hinton agar based on the Kirby-Bauer disk diffusion method.
\end{abstract}

Results: The overall prevalence of E. coli and Salmonella spp. was 52.5 and $27.5 \%$, respectively. The prevalence of the pathogenic E. coli was $61.90 \%$. The antibiogram profile of 21 E. coli as well as 11 Salmonella spp. revealed that all isolates, except one, were resistant to one to six antibiotics. Around 61.90\%, 71.43\%, 23.81\%, 61.90\%, 23.81\%, 19.05\%, and 52.38\% of $E$. coli showed resistance against amoxicillin, ampicillin, azithromycin, erythromycin, nalidixic acid, gentamicin, and tetracycline, respectively. Furthermore, E. coli resistance was not observed in case of ciprofloxacin and levofloxacin. Similarly, around $36.36 \%, 27.27 \%, 27.27 \%, 45.45 \%, 81.82 \%, 100 \%$, and $18.18 \%$ of the Salmonella spp. showed resistance against amoxicillin, ampicillin, azithromycin, erythromycin, nalidixic acid, tetracycline, and levofloxacin, respectively. However, all Salmonella spp. (100\%) were found to show sensitivity against ciprofloxacin and gentamicin. Multidrugresistant (MDR) E. coli (23.80\%) and Salmonella spp. (54.54\%) were also isolated. Furthermore, both positive (odds ratio $[\mathrm{OR}]>1$ ) and negative (OR $<1$ ) drug resistance associations, with a higher frequency of positive associations, were found in E. coli. A significant positive association was observed between ampicillin and amoxicillin (OR: $81.67,95 \%$ confidence interval: $2.73-2447.57, \mathrm{p}=0.01$ ).

Conclusion: Pigeon carrying MDR E. coli and Salmonella spp. may contribute to the transmission and spread of these microorganisms. Therefore, strict hygienic measures should be taken during the farming of pigeons to decrease the potential transmission of $E$. coli and Salmonella spp. from pigeon to humans as well as other animals. So far, this is the first report of the PCR-based identification of pathogenic E. coli from pigeons in Bangladesh.

Keywords: antimicrobial resistance, Escherichia coli, multidrug resistance, pigeon, Salmonella spp.

\section{Introduction}

The Asian subcontinent was a pioneer in rearing fancy pigeons. Emperor Akbar kept 20,000 pigeons

\footnotetext{
Copyright: Karim, et al. Open Access. This article is distributed under the terms of the Creative Commons Attribution 4.0 International License (http://creativecommons.org/licenses/by/4.0/), which permits unrestricted use, distribution, and reproduction in any medium, provided you give appropriate credit to the original author(s) and the source, provide a link to the Creative Commons license, and indicate if changes were made. The Creative Commons Public Domain Dedication waiver (http://creativecommons.org/ publicdomain/zero/1.0/) applies to the data made available in this
} article, unless otherwise stated. where 500 were selected [1] with the primary purpose of using them as postal messengers [2]. Furthermore, a long historical record can be found in Bangladesh in association with raising poultry in the backyard system [3]. Both domestic and feral pigeons (Columba livia) are commonly found in the rural as well as urban areas of Bangladesh. The vast spreading of the areas of crop fields and the weather of Bangladesh are suitable for pigeon farming and rearing to provide a source of nutrition for families, recreation, and income generation [4]. In Bangladesh, the most commonly found 
rock pigeon species is the Indian blue rock pigeon $-C$. livia intermedia [5].

Since pigeons are the potential hosts for various microorganisms, including Salmonella spp., Campylobacter, Escherichia coli, and Chlamydia, they pose significant threats to humans who remain in close contact with pigeons at their home, live-bird markets, and farms [6-8]. Healthy pigeons are important sources of salmonellosis for humans [9]. The occurrence of common diseases in pigeons in the northern part of Bangladesh varies significantly according to the current season and age of the birds. Younger citizens are more susceptible to salmonellosis and pigeon pox [10]. Moreover, the previous studies reported that bacterial infections (E. coli) for multiple species, including pigeons were found in Bangladesh [11]. Furthermore, a higher prevalence of Salmonella spp. was noticed in seemingly healthy pigeons and their carcasses that were reared and sold in live-bird markets, farms, and villages [9]. In yards and live-bird markets, the feces of pigeons largely contribute to the spreading of the infectious agents to the surrounding environment. Healthy pigeons may carry Salmonella spp., bearing zoonotic importance [12]. Furthermore, the meat of the pigeons might be contaminated with Salmonella spp. when it is prepared and kept unhygienically [13]. E. coli is one of the most recognized and important foodborne pathogen. Several animal species that are bred to provide food, including chicken, cattle, and pig, appear to be the host of these pathogenic microorganisms [14]. The feces of pigeons are a source of $E$. coli and they are extremely effective transmitters of $E$. coli to humans, birds, and mammals [15]. Regarding humans, a possible zoonotic risk from $E$. coli has been suggested, which triggers the appearance of urinary infections [16-18].

Antimicrobial resistance (AMR) limits the therapeutic possibilities of treatment associated with bacterial diseases in domestic animal species and poultry in particular [19]. Birds may host strains of AMR pathogens and disseminate them, posing a risk to humans [20]. The prevalence of AMR has been on the rise in regard to major bacterial pathogens [21]. Several animal species that are bred to provide food harbor multidrug-resistant (MDR) Salmonella spp. and become an emerging issue all over the world. Antibiotic-resistant zoonotic agents in an animal host potentially enter into humans through the food chain $[22,23]$.

This study was, therefore, designed to detect E. coli and Salmonella spp. from pigeons, especially in association with their antibiogram from seemingly healthy pigeons raised in households and farms in and around Dhaka city.

\section{Materials and Methods}

\section{Ethical approval and Informed consent}

Ethical approval is not required for such type of study. However, pigeons were handled carefully during collection of sample. Prior consent was taken from owner of the pigeon farm. The privacy and confidentiality of personal information of participating farm owners are not disclosed in the manuscript.

\section{Study period, location, sample collection and preparation}

A total of 40 samples, including both oral swabs $(n=20)$ and cloacal swabs $(n=20)$, were collected from 20 pigeons raised in farms and under household conditions around the Savar area as well as Sher-e-Bangla Agricultural University in Dhaka during the period of January-May 2017. One oral and one cloacal swab were collected from each bird subject. Swabs were placed into a tube that contained phosphate-buffered saline (PBS) immediately after the collection, which was transferred to the laboratory for analysis.

\section{Total viable count}

For the calculation of the total viable count, samples were diluted into 10-fold dilution series with sterile PBS. Diluted samples were subsequently cultured in nutrient agar at $37^{\circ} \mathrm{C}$. Colonies were counted and the results were expressed as $\mathrm{CFU} / \mathrm{ml}$. A portion of the sample was enriched in Luria-Bertani broth at $37^{\circ} \mathrm{C}$ overnight. Afterward, the total E. coli count as well as the total Salmonella spp. count (TSC) were plated in MacConkey (MC) agar and Salmonella-Shigella (SS) agar, respectively. Results were expressed as CFU/ml.

\section{Isolation and identification}

The isolation and characterization of $E$. coli and Salmonella spp. were performed as previously described [24,25]. E. coli and Salmonella spp. strains were isolated from the collected samples with a sterilized inoculating loop. The primary culture was plated on nutrient agar. Subcultures were subsequently plated on MC agar, eosin methylene blue (EMB) agar, brilliant green agar, and SS agar to get pure culture and cultural characteristics.

\section{Morphological characteristics}

The isolated E. coli and Salmonella spp. strains were stained by Gram's stain according to the procedure described earlier [24].

\section{Biochemical test}

Biochemical tests, including the carbohydrate fermentation test, the triple sugar iron agar slant reaction, the indole test, the methyl red (MR) test, the catalase test, as well as the Voges-Proskauer (VP) test, were performed according to the procedures described previously [24,25].

\section{DNA extraction}

For DNA extraction, individual E. coli was cultured in a nutrient broth. About $1.0 \mathrm{~mL}$ of the broth cultured overnight was spanned at 12,000 rpm for $3 \mathrm{~min}$. After decanting the supernatant, the bacterial pellet was resuspended in $467 \mu \mathrm{L}$ TE buffer. Subsequently, $30 \mu \mathrm{L}$ of $10 \%$ sodium dodecyl sulfate (SDS) and $3 \mu \mathrm{L}$ of proteinase $\mathrm{K}$ were added to give a final concentration of $100 \mu \mathrm{g} / \mathrm{ml}$ proteinase $\mathrm{K}$ in $0.5 \%$ SDS. The mixture was 
then shaken and incubated for $1 \mathrm{~h}$ at $37^{\circ} \mathrm{C}$. An equal volume of $500 \mu \mathrm{L}$ of phenol/chloroform/isoamyl alcohol was added and mixed thoroughly by inverting the tube until the phases got completely mixed. Afterward, the sample was centrifuged at $12,000 \mathrm{rpm}$ for $10 \mathrm{~min}$. Following the centrifugation, the aqueous and viscous supernatant $(\sim 450 \mu \mathrm{L})$ was transferred to a fresh microcentrifuge tube and an equal volume of phenol/ chloroform/isoamyl alcohol was added, mixed, and the mixture was further spanned at 12,000 rpm for $5 \mathrm{~min}$. The supernatant was then transferred to a fresh tube $(\sim 400 \mu \mathrm{L})$ and about $1 / 10^{\text {th }}$ volume of $3 \mathrm{M}$ sodium acetate was added. Subsequently, 0.6 volumes of isopropanol were added and kept on ice for $10 \mathrm{~min}$ for DNA precipitation. The mixture was then centrifuged at 13,500 rpm for $15 \mathrm{~min}$. The supernatant was decanted, and $1 \mathrm{~mL}$ of $95 \%$ ethanol was added and kept at room temperature for $5 \mathrm{~min}$. Finally, the mixture was centrifuged at 12,000 rpm for $10 \mathrm{~min}$. After decanting, the supernatant DNA pellet was dried and resuspended in DNase-free water.

\section{Polymerase chain reaction (PCR)}

PCR reactions were performed in a total volume of $25 \mu \mathrm{L}$, including $1.5 \mathrm{mM} \mathrm{MgCl}, 50 \mathrm{mM}$ $\mathrm{KCl}, 10 \mathrm{mM}$ Tris- $\mathrm{HCl}$ (pH 9.0), $0.1 \%$ Triton X-100, $200 \mu \mathrm{M}$ of each dNTP, $1 \mu \mathrm{M}$ primers (Table-1), 1 unit of Taq DNA polymerase, as well as $100 \mathrm{ng}$ of DNA. A thermocycler was used to carry out amplification reactions (GeneAtlas, Model: G02, Japan) as follows: The initial denaturation was set to $5 \mathrm{~min}$ at $95^{\circ} \mathrm{C}$, followed by 35 cycles with each cycle consisting of $1 \mathrm{~min}$ at $94^{\circ} \mathrm{C}, 90 \mathrm{~s}$ at $\sim 55^{\circ} \mathrm{C}$, and $1 \mathrm{~min}$ at $72^{\circ} \mathrm{C}$, and a subsequent final extension was set to 10 $\min$ at $72^{\circ} \mathrm{C}$ [26]. Afterward, electrophoresis was used to analyze amplicons in $1.5 \%$ agarose gel stained with ethidium bromide. A molecular weight marker with $100 \mathrm{bp}$ increments (100 bp DNA ladder) was used as a standard. Positive and negative controls were also used along with test samples.

\section{Antibiotic sensitivity assay}

The isolated E. coli and Salmonella spp. were subjected to an antimicrobial sensitivity test against nine commonly used antibiotics of different groups by the Kirby-Bauer disk diffusion method [27]. Briefly, the overnight grown bacterial inoculums were adjusted to the 0.5 McFarland standard, swabbed on pre-incubated Mueller-Hinton agar (MHA) plates by a sterile cotton swab, and subsequently left for

Table-1: PCR primers with sequence.

\begin{tabular}{llcc}
\hline Primer & Sequence $\left(5^{\prime \prime}-\mathbf{3}^{\prime}\right)$ & $\begin{array}{l}\text { Size } \\
\text { (bp) }\end{array}$ & Reference \\
\hline E. coli & GGGAGTAAAGTTAATC & $584 \mathrm{bp}$ & {$[26]$} \\
$16 \mathrm{E} 1(\mathrm{~F})$ & CTTTGCTC & & \\
E. coli & TTCCCGAAGGCACATTCT & & \\
$16 \mathrm{E} 2(\mathrm{R})$ & & & \\
E. coli & TTCCCGAAGGCACCAATC & & \\
$16 \mathrm{E} 3(\mathrm{R})$ & & & \\
\hline
\end{tabular}

E. coli=Escherichia coli, $\mathrm{PCR}=$ Polymerase chain reaction
10-15 min to dry. Afterward, standard antibiotic disks (Oxoid Ltd., U.K.) were placed on MHA plates with sterile forceps and aerobic incubation took place at $37^{\circ} \mathrm{C}$ for $24 \mathrm{~h}$. Following the incubation, the organisms were categorized as "resistant" or "susceptible" based on the diameter of their zone of inhibition according to the CLSI guidelines [28]. Antibiotic classes and antibiotics chosen for this study include the following compounds: Penicillin antibiotics (ampicillin - $10 \mu \mathrm{g} /$ disk), beta-lactam antibiotics (amoxicillin - $10 \mu \mathrm{g} /$ disk), macrolides (erythromycin $-15 \mu \mathrm{g} /$ disk and azithromycin $-15 \mu \mathrm{g} /$ disk), tetracyclines (tetracycline $-30 \mu \mathrm{g} /$ disk), quinolones (nalidixic acid - $30 \mu \mathrm{g} /$ disk), fluoroquinolones (ciprofloxacin $-5 \mu \mathrm{g} /$ disk and levofloxacin $-5 \mu \mathrm{g} /$ disk), as well as aminoglycosides (gentamicin $-10 \mu \mathrm{g} / \mathrm{disk}$ ).

MDR in Enterobacteriaceae, including E. coli, is defined as being resistant to at least one drug from three or more of the following antimicrobial classes: Aminoglycosides (i.e., gentamicin, tobramycin, amikacin, or netilmicin), fluoroquinolones (i.e., ciprofloxacin), penicillin antibiotics (i.e., ampicillin), tetracyclines (i.e., tetracycline, doxycycline, or minocycline), phenols (i.e., chloramphenicol), and folate pathway inhibitors (i.e., trimethoprim-sulfamethoxazole), among others [29]. Resistant and intermediate sensitive isolates were considered as non-susceptible during the calculation of the MDR phenotype [29].

\section{Results}

\section{Bacterial load}

The bacterial load was determined from $40 \mathrm{swab}$ samples (20 oral and 20 cloacal swabs) obtained from 20 pigeons that were taken from two different regions (Dhaka and Savar) and reared under two different conditions, the household as well as the small farm condition. In general, $100 \%$ of the samples were found positive for the total viable count and bacterial load that ranged between $7 \times 10^{4}$ and $3.8 \times 10^{9} \mathrm{CFU} / \mathrm{ml}$. E. coli and Salmonella spp. were found in $52.5 \%$ and $27.5 \%$ of the samples, respectively. Furthermore, the coliform count was found to vary between $8 \times 10^{4}$ and $6.8 \times 10^{9} \mathrm{CFU} / \mathrm{ml}$, whereas Salmonella spp. load varied between $1.3 \times 10^{5}$ and $3.6 \times 10^{9} \mathrm{CFU} / \mathrm{ml}$ (Table-2). In addition, the prevalence rate and bacterial load varied among the selected region, rearing system, and the type of the sample. The total viable count $\left(3.4 \times 10^{9}\right.$ $\mathrm{CFU} / \mathrm{ml})$ and the coliform count $\left(6.8 \times 10^{9} \mathrm{CFU} / \mathrm{ml}\right)$ were found to be higher in the oral swab samples of pigeons reared under the household condition in the Savar region. On the other hand, the TSC was found to be higher $\left(2.7 \times 10^{9} \mathrm{CFU} / \mathrm{ml}\right)$ in the cloacal swab samples of pigeons from the same region (Table-2).

\section{Identification of $E$. coli}

E. coli sample on the EMB agar produced a greenish-black colony with a metallic sheen, whereas on the MC agar, it produced bright, pink-colored, transparent smooth and raised colonies. Pink-colored, rod-shaped, short chain, single or paired Gram-negative bacilli 
Table-2: Total viable count, Escherichia coli count, and Salmonella spp. count in the swab samples of pigeon $(n=40)$.

\begin{tabular}{|c|c|c|c|c|c|c|c|c|}
\hline \multirow[t]{3}{*}{ Category } & \multirow[t]{3}{*}{ Sample type } & \multirow{3}{*}{$\begin{array}{c}\text { Number } \\
\text { of sample } \\
\text { tested }\end{array}$} & \multicolumn{6}{|c|}{ Microorganism count (CFU/ml) } \\
\hline & & & \multicolumn{2}{|c|}{ Total viable } & \multicolumn{2}{|c|}{ Total Escherichia coli } & \multicolumn{2}{|c|}{ Total Salmonella spp. } \\
\hline & & & $\begin{array}{c}\text { Number of } \\
\text { positive }(\%)\end{array}$ & $\begin{array}{c}\text { Bacterial } \\
\text { load }\end{array}$ & $\begin{array}{c}\text { Number of } \\
\text { positive (\%) }\end{array}$ & $\begin{array}{l}\text { Bacterial } \\
\text { load }\end{array}$ & $\begin{array}{c}\text { Number of } \\
\text { positive (\%) }\end{array}$ & $\begin{array}{c}\text { Bacterial } \\
\text { load }\end{array}$ \\
\hline \multicolumn{9}{|c|}{ Sample from around Savar } \\
\hline \multirow[t]{2}{*}{ Household } & Oral swab & 10 & $10(100)$ & $\begin{array}{l}1.6 \times 10^{5} \\
3.8 \times 10^{9}\end{array}$ & $6(60)$ & $\begin{array}{l}0.8 \times 10^{5}- \\
6.8 \times 10^{9}\end{array}$ & $2(20)$ & $\begin{array}{c}1.6 \times 10^{5}- \\
1.8 \times 10^{5}\end{array}$ \\
\hline & Cloacal swab & 10 & $10(100)$ & $\begin{array}{l}1.8 \times 10^{5}- \\
3.4 \times 10^{9}\end{array}$ & $5(50)$ & $\begin{array}{c}3.1 \times 10^{6}- \\
5.7 \times 10^{9}\end{array}$ & $2(20)$ & $\begin{array}{c}1.8 \times 10^{5}- \\
2.7 \times 10^{9}\end{array}$ \\
\hline \multicolumn{9}{|c|}{ Sample from around Sher-e-Bangla Agricultural University, Dhaka } \\
\hline \multirow[t]{2}{*}{ Small farm } & Oral swab & 10 & $10(100)$ & $\begin{array}{l}0.7 \times 10^{5}- \\
3.6 \times 10^{9}\end{array}$ & $4(40)$ & $\begin{array}{l}1.7 \times 10^{9}- \\
6.5 \times 10^{9}\end{array}$ & $4(40)$ & $\begin{array}{c}1.3 \times 10^{5} \\
3.6 \times 10^{9}\end{array}$ \\
\hline & Cloacal swab & 10 & $10(100)$ & $\begin{array}{l}1.3 \times 10^{5}- \\
3.6 \times 10^{9}\end{array}$ & $6(60)$ & $\begin{array}{l}2.9 \times 10^{7}- \\
4.1 \times 10^{9}\end{array}$ & $3(30)$ & $\begin{array}{l}1.3 \times 10^{5}- \\
2.5 \times 10^{9}\end{array}$ \\
\hline $\begin{array}{l}\text { Overall } \\
\text { prevalence }\end{array}$ & & 40 & $40(100)$ & & $21(52.5)$ & & $11(27.5)$ & \\
\hline
\end{tabular}

E. coli=Escherichia coli

were observed after the application of the Gram's staining. The five basic sugars were fermented, including dextrose, sucrose, lactose, maltose, and mannitol, with the production of both acid and gas. Acid production was indicated by a color change from reddish to yellow and gas production was noted by the presence of gas bubbles in the inverted Durham's tubes. Each E. coli isolate was catalase, indole, M-R positive, and $\mathrm{V}-\mathrm{P}$ negative. Afterward, a molecular identification was conducted.

\section{Identification of Salmonella spp.}

Salmonella spp. formed smooth, small, round, and black-centered colonies on the S-S agar as well as showed a colorless, smooth, and transparent appearance on the MC's agar. Salmonella spp. showed a structure made of Gram-negative (pink) rods that were arranged in a single form or pairs according to the Gram's method. The carbohydrate fermentation test showed that Salmonella spp. fermented maltose, dextrose, and mannitol and produced both acid and gas, whereas it did not ferment sucrose and lactose. The MR test was positive, whereas the VP and the indole tests were negative.

\section{Prevalence of $E$. coli}

The overall prevalence of $E$. coli was found to be $52.50 \%(\mathrm{n}=21 / 40)$. The prevalence was $50 \%$ $(\mathrm{n}=10 / 20)$ in oral swabs and $55 \%(\mathrm{n}=11 / 20)$ in cloacal swabs (Table-3). Furthermore, the prevalence was recorded to be $55 \%(11 / 20)$ in pigeons reared at farms and $50 \%(10 / 20)$ in pigeons reared at under the household conditions (Table-4).

\section{Prevalence of Salmonella spp.}

The overall prevalence of Salmonella spp. was found to be $27.50 \%(n=11 / 40)$. The prevalence was $30 \%(n=6 / 20)$ in oral swabs and $25 \%(n=5 / 20)$ in cloacal swabs (Table-3). Moreover, the prevalence was recorded to be $20 \%(4 / 20)$ in pigeons reared at farms and $35 \%(7 / 20)$ in pigeons reared under the household conditions (Table-4).
Table-3: Prevalence of E. coli and Salmonella spp. in oral and cloacal swabs of pigeons.

\begin{tabular}{lccc}
\hline Sources & $\begin{array}{c}\text { Number } \\
\text { of sample } \\
\text { tested }\end{array}$ & $\begin{array}{c}\text { Number } \\
\text { of sample } \\
\text { positive }\end{array}$ & $\begin{array}{c}\text { Prevalence } \\
\text { (\%) }\end{array}$ \\
\hline E. coli & & & \\
$\quad$ Oral swabs & 20 & 10 & 50 \\
Cloacal swabs & 20 & 11 & 55 \\
Overall & 40 & 21 & 52.5 \\
Salmonella spp. & & & \\
$\quad$ Oral swabs & 20 & 6 & 30 \\
Cloacal swabs & 20 & 5 & 25 \\
Overall & 40 & 11 & 27.5 \\
\hline
\end{tabular}

E. coli=Escherichia coli

Table-4: Prevalence of E. coli and Salmonella spp. in pigeons according to rearing system.

\begin{tabular}{lccc}
\hline $\begin{array}{l}\text { Rearing } \\
\text { system }\end{array}$ & $\begin{array}{c}\text { Number } \\
\text { of sample } \\
\text { tested }\end{array}$ & $\begin{array}{c}\text { Number } \\
\text { of sample } \\
\text { positive }\end{array}$ & $\begin{array}{c}\text { Prevalence } \\
(\%)\end{array}$ \\
\hline E. coli & & & \\
$\quad$ Household & 20 & 10 & 50 \\
$\quad$ Small farm & 20 & 11 & 55 \\
$\begin{array}{l}\text { Overall } \\
\text { Salmonella }\end{array}$ & 40 & 21 & 52.5 \\
$\quad$ Household & 20 & 7 & 35 \\
Small farm & 20 & 4 & 20 \\
Overall & 40 & 11 & 27.5 \\
\hline
\end{tabular}

E. coli=Escherichia coli

\section{Molecular identification of $E$. coli}

DNA isolated from $21 \mathrm{E}$. coli samples was subjected to PCR amplification. The $584 \mathrm{bp}$ fragments of the 16S rRNA gene could be amplified from all the isolates, as shown in the representative figure (Figure-1). Furthermore, it was found that 584 bp PCR products could be generated by the primer $16 \mathrm{E} 1+16 \mathrm{E} 2$ only from six strains (strain 3, 4, 6, 8, 9, and 10) isolated from pigeons reared under the household conditions and from seven strains (strain 2, 3, 5, 6, 7, 9, and 10) isolated from pigeons reared under the small farm conditions. In addition, these isolates were found to be pathogenic $(61.90 \%)$. On the other hand, 584 bp PCR products 
could be generated by the primer $16 \mathrm{E} 1+16 \mathrm{E} 3$ only from four strains (strain 1, 2, 5, and 7) isolated from pigeons reared under the household conditions, and four strains (strain 1, 4, 8, and 11) isolated from pigeons reared under the small farm conditions. Furthermore, these isolates were found to be non-pathogenic (38.10\%). However, all E. coli strains, both pathogenic and non-pathogenic $(100 \%)$, that were tested generated the expected PCR products of $584 \mathrm{bp}$ when all the three primers $(16 \mathrm{E} 1+16 \mathrm{E} 2+16 \mathrm{E} 3)$ were used together (Table-5).

\section{Antibiotic sensitivity}

Twenty-one E. coli isolates from the pigeon samples were subjected to antibiogram profiling with nine antibiotics. Regarding the results, all the tested bacteria $(100 \%)$ were found to be sensitive to ciprofloxacin and levofloxacin. However, about $61.90 \%, 71.43 \%$, $23.81 \%, 61.90 \%, 23.81 \%, 19.05 \%$, and $52.38 \%$ of E. coli isolates were found to be resistant to amoxicillin, ampicillin, azithromycin, erythromycin, nalidixic acid, gentamicin, and tetracycline, respectively. Similarly, Salmonella spp. $(\mathrm{n}=11)$ isolates from pigeon were subjected to antibiogram profiling and about $36.36 \%$, $27.27 \%, 27.27 \%, 45.45 \%, 81.82 \%, 100 \%$, and $18.18 \%$ of Salmonella spp. isolates were found to be resistant to amoxicillin, ampicillin, azithromycin, erythromycin, nalidixic acid, tetracycline, and levofloxacin, respectively. Moreover, all Salmonella spp. (100\%) isolates were found to be sensitive to ciprofloxacin and gentamicin. These results varied according to the type of the sample and the rearing system (Table-6).

\section{MDR bacteria}

In general, about $95.24 \%(20 / 21)$ of $E$. coli isolates and $100 \%(11 / 11)$ of Salmonella spp. isolates were found to be resistant to at least one of the antibiotics used in this study. Only one E. coli isolate was found to be sensitive to all the tested antibiotics. Microorganisms that showed resistance to three or more antibiotics of three different classes were considered to be MDR. However, macrolides were not included in the MDR calculations. Overall, about $23.80 \%$ and $54.54 \%$ of E. coli and Salmonella spp. isolates were found to carry MDR traits, respectively. With the inclusion of the macrolides, a maximum of six antibiotics were found to be ineffective against one isolate of $E$. coli. However, without the application of macrolides, a resistance against 3-4 antibiotic compounds was found in MDR isolates (Table-7).

\section{Associations among AMR phenotypes}

Phenotypic resistance to each of the applied drugs was found to be probably associated with phenotypic resistance to another drug (Table-8). Both positive (odds ratio $[\mathrm{OR}]>1$ ) and negative $(\mathrm{OR}<1)$ associations were identified in this study, among which higher frequencies of positive associations were observed for E. coli than Salmonella. In the case of E. coli, a significant positive association of AMR was observed between the ampicillin/amoxicillin antibiotic pair (OR: 81.67\%, 95\% CI: 2.73-2447.57, $\mathrm{p}=0.01$ ). Besides, a statistically non-significant positive association was also revealed between the amoxicillin/tetracycline (OR: 16, 95\% CI: 0.96-267.05, $\mathrm{p}=0.06$ ), the amoxicillin/gentamicin (OR: 15.93, 95\% CI: $0.74-345.09, \mathrm{p}=0.08$ ), as well as the azithromycin/tetracycline (OR: 7.64, 95\% CI: 0.81-72.41, $\mathrm{p}=0.08$ ) antibiotic pairs. In the case of Salmonella, non-significant positive associations were detected.

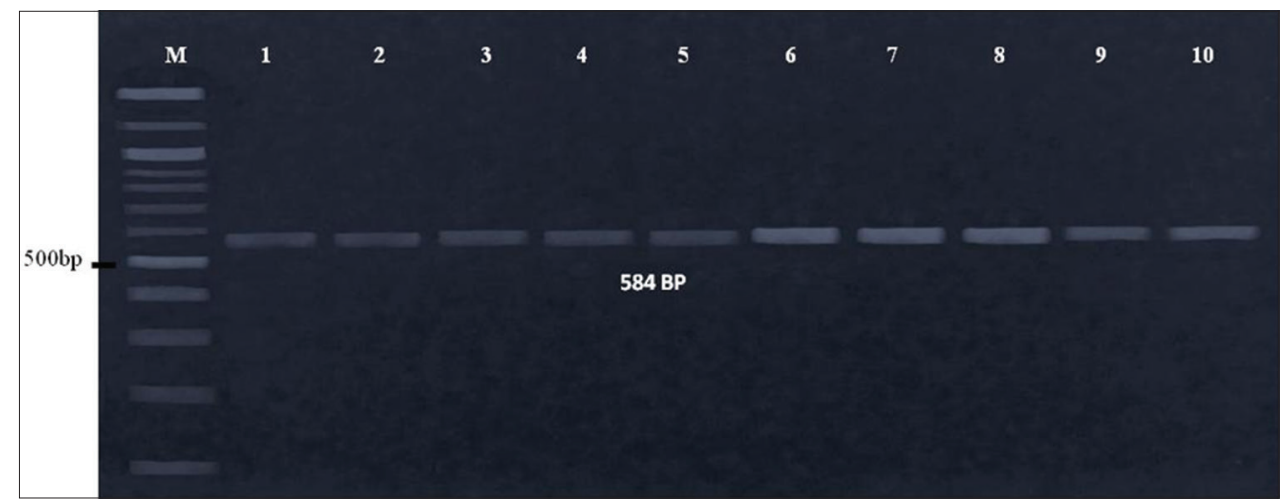

Figure-1: Molecular detection and differentiation of Escherichia coli. About 584 bp fragment of 16s rRNA gene was amplified. Lane M: DNA marker, lane 1-5: Test sample, polymerase chain reaction (PCR) with 16E1+E2 primer, lane 6-10: Test sample, PCR with 16E1+16E3 primer.

Table-5: Detection of E. coli by PCR.

\begin{tabular}{lcccc}
\hline $\begin{array}{l}\text { Source of } \\
\text { E. coli }\end{array}$ & $\begin{array}{c}\text { Number of } \\
\text { isolate tested }\end{array}$ & \multicolumn{2}{c}{ Detection of different E. coli by primer set } \\
\cline { 3 - 5 } & & $\begin{array}{c}\text { 16E1+16E2 } \\
\text { pathogenic }\end{array}$ & $\begin{array}{c}\text { 16E1+16E3 } \\
\text { non-pathogenic }\end{array}$ & $\begin{array}{c}\text { 16E1+16E2+16E3 } \\
\text { both pathogenic and non-pathogenic (\%) }\end{array}$ \\
\hline Household & 10 & $6(60.00)$ & $4(40.00)$ & $100(100)$ \\
Small farm & 11 & $7(63.64)$ & $4(36.36)$ & $11(100)$ \\
Overall & 21 & $13(61.90)$ & $8(38.10)$ & $21(100)$ \\
\hline
\end{tabular}

E. coli=Escherichia coli, $\mathrm{PCR}=$ Polymerase chain reaction 
Table-6: Antibiogram profile of E. coli and Salmonella spp. to different antimicrobials.

\begin{tabular}{|c|c|c|c|c|c|c|c|c|c|c|}
\hline \multirow{2}{*}{$\begin{array}{l}\text { Name of } \\
\text { samples }\end{array}$} & \multirow{2}{*}{$\begin{array}{c}\text { Number } \\
\text { of isolates } \\
\text { tested }\end{array}$} & \multicolumn{9}{|c|}{ Number and percentage of microorganisms resistant to antimicrobials } \\
\hline & & AMX & AMP & AZM & ERY & NA & CIP & $\mathbf{G M}$ & TET & LEV \\
\hline \multicolumn{11}{|l|}{ E. coli } \\
\hline $\begin{array}{l}\text { Oral } \\
\text { swabs }\end{array}$ & 10 & $4(40)$ & $6(60)$ & $4(40)$ & $5(50)$ & $4(40)$ & $0(0)$ & $2(20)$ & $7(70)$ & $0(0)$ \\
\hline $\begin{array}{l}\text { Cloacal } \\
\text { swabs }\end{array}$ & 11 & $9(81.81)$ & $9(81.81)$ & $1(9.09)$ & $8(72.72)$ & $1(9.09)$ & $0(0)$ & $2(18.18)$ & $4(36.36)$ & $0(0)$ \\
\hline Total & 21 & $13(61.90)$ & $15(71.43)$ & $5(23.81)$ & $13(61.90)$ & $5(23.81)$ & $0(0)$ & $4(19.05)$ & $11(52.38)$ & $0(0)$ \\
\hline \multicolumn{11}{|c|}{ 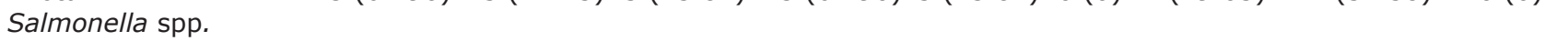 } \\
\hline $\begin{array}{l}\text { Oral } \\
\text { swabs }\end{array}$ & 6 & $2(33.33)$ & $2(33.33)$ & $2(33.33)$ & $3(50)$ & $5(83.33)$ & $0(0)$ & $0(0)$ & $6(100)$ & $2(33.33)$ \\
\hline $\begin{array}{l}\text { Cloacal } \\
\text { swabs }\end{array}$ & 5 & $2(40)$ & $1(20)$ & $1(20)$ & $2(40)$ & $4(80)$ & $0(0)$ & $0(0)$ & $5(100)$ & $0(0)$ \\
\hline Total & 11 & $4(36.36)$ & $3(27.27)$ & $3(27.27)$ & $5(45.45)$ & $9(81.82)$ & $0(0)$ & $0(0)$ & $11(100)$ & $2(18.18)$ \\
\hline
\end{tabular}

$\mathrm{AMX}=$ Amoxicillin, $\mathrm{AMP}=$ Ampicillin, $\mathrm{AZM}=$ Azithromycin, $E R Y=$ Erythromycin, NA=Nalidixic acid, CIP=Ciprofloxacin, $\mathrm{GM}=$ Gentamicin, TET=Tetracycline, LEV=Levofloxacin, (zone diameter interpretive standard [mm] resistant $\leq 13$, intermediate 14-17, susceptible $\geq 18), E$. coli=Escherichia coli

Table-7: Multidrug-resistant E. coli $(\mathrm{n}=21)$ and Salmonella spp. $(n=11)$ isolated from pigeons. ${ }^{a}$

\begin{tabular}{llc}
\hline $\begin{array}{l}\text { Antimicrobial } \\
\text { compound }\end{array}$ & $\begin{array}{l}\text { Antibiotic } \\
\text { class }\end{array}$ & $\begin{array}{c}\text { Number of MDR } \\
\text { isolates (\%) }\end{array}$ \\
\hline E. coli $(\mathrm{n}=21)$ & Pen-Qui-Ami & $1(4.76)$ \\
AMP, NA, GM & Pen-Bet-Ami & $1(4.76)$ \\
AMP, AMX, GM & PMY, & $1(4.76)$ \\
AMP, AMX, NA, TET & Pen-Bet-Qui-Tet & $1(4.76)$ \\
AMP, AMX, GM, TET & Pen-Bet-Tet-Ami & $1(4.76)$ \\
AMP, NA, GM, TET & Pen-Qui-Tet-Ami & $1(23.80)$ \\
Total & & 5 \\
Salmonella spp. $(\mathrm{n}=11)$ & \\
AMP, NA, TET & Pen-Qui-Tet & $2(18.18)$ \\
AMX, NA, TET & Bet-Qui-Tet & $2(18.18)$ \\
NA, TET, LEV & Qui-Tet-Flu & $1(9.09)$ \\
AMP, NA, TET, LEV & Pen-Qui-Tet-Flu & $1(9.09)$ \\
Total & & $6(54.54)$ \\
\hline
\end{tabular}

aMDR was calculated according to Magiorakos

et al. [29]. Hence, macrolides are not included in MDR calculation. $A M X=$ Amoxicillin, $A M P=$ Ampicillin, $A Z M=$ Azithromycin, $E R Y=$ Erythromycin, $N A=$ Nalidixic acid CIP=Ciprofloxacin, GM=Gentamicin, TET=Tetracycline, LEV =Levofloxacin, Ami=Aminoglycosides, Pen=Penicillins, Tet=Tetracyclines, Bet=Beta-lactams, Qui=Quinolones, $\mathrm{Flu}=$ Fluoroquinolones, $E$. coli=Escherichia coli, MDR=Multidrug-resistant

Remarkable non-significant positive associations include the resistance for tetracycline/nalidixic acid (OR: 23, 95\% CI: 0.19-2896.22, p=0.21), ampicillin/ciprofloxacin, (OR: 9.30, 95\% CI: 0.35-252.47, $\mathrm{p}=0.19$ ), and amoxicillin/gentamicin (OR: $8,95 \% \mathrm{CI}$ : 0.51-127.91, $\mathrm{p}=0.15$ ).

\section{Discussion}

Domestic and feral pigeons (C. livia) were commonly found in rural and urban areas of Bangladesh throughout the history of the region. The tradition of pigeon rearing in the Indian subcontinent can be traced back to the Mughal era when pigeons were primarily used as postal messengers. Nowadays, pigeons are commonly raised for racing, fighting, exhibition, as well as for the nutritional and therapeutic values of the pigeon meat [2]. Pigeon farming is gaining popularity among students because only a low level of investment is needed, less technical complexity is required, the requirements in association with space for rearing are low, the housing of pigeons is simple, their marketing is easy, as well as the maximum profit can be high, and so on. However, it must be ensured that pigeons do not get afflicted with diseases, especially as pigeons are mostly reared in and around the same house as their owner. Besides, humans can get into contact with pigeons with a high possibility in smallholdings, parks, temples, shrines, public gardens, and railroad stations [30]. Therefore, they may transmit disease agents to other birds as well as their handlers. Moreover, the live-bird market, the trading place of different species of live poultry, including pigeons, may play a significant role in the transmission of the associated microorganisms. Similar to the diseases associated with chickens, pigeons of Bangladesh are affected with salmonellosis and colibacillosis. The present research aimed to isolate, identify, and characterize E. coli and Salmonella spp. from pigeons raised in under the household and small farms conditions around the Savar region and the Sher-e-Bangla Agricultural University, Dhaka, with the molecular identification of E. coli based on PCR. Forty samples were analyzed in this study and the prevalence was found to be $52.5 \%(21 / 40)$ for E. coli isolates (Tables-3 and 4). The prevalence is slightly lower than the prevalence reported by Dey et al. [31]. In that study, 112 samples obtained from seemingly healthy pigeons of different places of the Mymensingh district were analyzed and $69.64 \%$ prevalence of $E$. coli was reported. Besides, a cross-sectional study on 108 dead pigeons was conducted to explore the diseases and conditions associated with the death of pigeons reared in different regions at smallholdings which were sold at live-bird markets in Bangladesh. In this study, results showed that $13.89 \%$ of all deaths were accounted to colibacillosis [30]. Sample size and regional variation, among other factors, may be important factors that contributed to the differences among the results 
Table-8: Pairwise association of antibiotic resistance phenotypes in Escherichia coli (lower panel) and Salmonella spp. (upper panel) isolated from pigeon. ${ }^{\mathrm{a}}$

\begin{tabular}{|c|c|c|c|c|c|c|c|c|c|}
\hline & AMP & AMX & ERY & AZM & TET & NA & CIP & LEV & GEN \\
\hline AMP & & $\begin{array}{c}0.34 \\
(0.03- \\
3.93) \\
0.40\end{array}$ & $\begin{array}{c}0.80 \\
0.04- \\
17.20) \\
0.89\end{array}$ & $\begin{array}{c}1.50 \\
(0.14- \\
16.55) \\
0.75\end{array}$ & $\begin{array}{c}0.85 \\
(0.02- \\
50.11) \\
0.94\end{array}$ & $\begin{array}{c}0.85 \\
(0.02- \\
50.11) \\
0.94\end{array}$ & $\begin{array}{c}9.30 \\
(0.35- \\
252.47) \\
0.19\end{array}$ & $\begin{array}{c}3.00 \\
(0.26- \\
35.34) \\
0.39\end{array}$ & $\begin{array}{c}0.13 \\
(0.01- \\
1.10) \\
0.15\end{array}$ \\
\hline AMX & $\begin{array}{c}81.67 \\
(2.73- \\
2447.57) \\
0.01\end{array}$ & & $\begin{array}{c}0.17 \\
(0.01- \\
4.36) \\
0.28\end{array}$ & $\begin{array}{c}3 \\
(0.26- \\
35.34) \\
0.39\end{array}$ & $\begin{array}{c}1.19 \\
(0.020- \\
69.99) \\
0.94\end{array}$ & $\begin{array}{c}1.19 \\
(0.020- \\
69.99) \\
0.94\end{array}$ & $\begin{array}{c}0.11 \\
(0.01- \\
2.93) \\
0.19\end{array}$ & $\begin{array}{c}0.34 \\
(0.03-3.93) \\
0.39\end{array}$ & $\begin{array}{c}8 \\
(0.51- \\
127.91) \\
0.15\end{array}$ \\
\hline ERY & $\begin{array}{c}5.28 \\
(0.09- \\
313.60) \\
0.43\end{array}$ & $\begin{array}{c}3.89 \\
(0.07- \\
224.24) \\
0.52\end{array}$ & & $\begin{array}{c}1.25 \\
(0.06- \\
26.88) \\
0.89\end{array}$ & $\begin{array}{c}3.80 \\
(0.06- \\
243.53) \\
0.53\end{array}$ & $\begin{array}{c}3.80 \\
(0.06- \\
243.53) \\
0.53\end{array}$ & $\begin{array}{c}1.67 \\
(0.06- \\
47.84) \\
0.77\end{array}$ & $\begin{array}{c}0.11 \\
(0.01-2.93) \\
0.19\end{array}$ & $\begin{array}{c}4.10 \\
(0.16- \\
108.95) \\
0.40\end{array}$ \\
\hline AZM & $\begin{array}{c}0.25 \\
(0.02- \\
3.35) \\
0.30\end{array}$ & $\begin{array}{c}0.14 \\
(0.02- \\
1.68) \\
0.13\end{array}$ & $\begin{array}{c}0.63 \\
(0.02- \\
34.83) \\
0.83\end{array}$ & & $\begin{array}{c}1.19 \\
(0.02- \\
69.98) \\
0.94\end{array}$ & $\begin{array}{c}1.19 \\
(0.02- \\
69.98) \\
0.94\end{array}$ & $\begin{array}{c}0.34 \\
(0.03- \\
3.93) \\
0.39\end{array}$ & $\begin{array}{c}0.34 \\
(0.03-3.93) \\
0.39\end{array}$ & $\begin{array}{c}1.50 \\
(0.14- \\
16.55) \\
0.75\end{array}$ \\
\hline TET & $\begin{array}{c}4 \\
(0.24- \\
66.77) \\
0.34\end{array}$ & $\begin{array}{c}16 \\
(0.96- \\
267.05) \\
0.06\end{array}$ & $\begin{array}{c}5.29 \\
(0.09- \\
313.60) \\
0.43\end{array}$ & $\begin{array}{c}1.28 \\
(0.09- \\
16.81) \\
0.86\end{array}$ & & $\begin{array}{c}23 \\
(0.19- \\
2896.22) \\
0.21\end{array}$ & $\begin{array}{c}0.27 \\
(0.01- \\
16.87) \\
0.53\end{array}$ & $\begin{array}{c}0.85 \\
(0.02- \\
50.11) \\
0.94\end{array}$ & $\begin{array}{c}0.85 \\
(0.02- \\
50.11) \\
0.94\end{array}$ \\
\hline NA & $\begin{array}{c}0.47 \\
(0.02- \\
10.71) \\
0.63\end{array}$ & $\begin{array}{c}0.34 \\
(0.02- \\
7.48) \\
0.49\end{array}$ & $\begin{array}{c}3.89 \\
(0.07- \\
224.24) \\
0.52\end{array}$ & $\begin{array}{c}2.10 \\
(0.18- \\
24.60) \\
0.56\end{array}$ & $\begin{array}{c}0.47 \\
(0.02- \\
10.71) \\
0.63\end{array}$ & & $\begin{array}{c}0.27 \\
(0.01- \\
16.87) \\
0.53\end{array}$ & $\begin{array}{c}0.85 \\
(0.02- \\
50.11) \\
0.94\end{array}$ & $\begin{array}{c}0.85 \\
(0.02- \\
50.11) \\
0.94\end{array}$ \\
\hline CIP & $\begin{array}{c}1.28 \\
(0.10- \\
16.81) \\
0.86\end{array}$ & $\begin{array}{c}0.55 \\
(0.07- \\
4.92) \\
0.59\end{array}$ & $\begin{array}{c}0.63 \\
(0.02- \\
34.83) \\
0.83\end{array}$ & $\begin{array}{c}5.56 \\
(0.81- \\
38.17) \\
0.08\end{array}$ & $\begin{array}{c}1.28 \\
(0.10- \\
16.81) \\
0.86\end{array}$ & $\begin{array}{c}2.10 \\
(0.18- \\
24.60) \\
0.56\end{array}$ & & $\begin{array}{c}1.25 \\
(0.06- \\
26.88) \\
0.89\end{array}$ & $\begin{array}{c}0.17 \\
(0.01- \\
4.36) \\
0.28\end{array}$ \\
\hline LEV & $\begin{array}{c}0.20 \\
(0.02- \\
2.63) \\
0.22\end{array}$ & $\begin{array}{c}0.11 \\
(0.01- \\
1.29) \\
0.08\end{array}$ & $\begin{array}{c}0.52 \\
(0.01- \\
28.76) \\
0.75\end{array}$ & $\begin{array}{c}3.34 \\
(0.51- \\
22.15) \\
0.22\end{array}$ & $\begin{array}{c}0.05 \\
(0.01- \\
1.04) \\
0.06\end{array}$ & $\begin{array}{c}6.43 \\
(0.30- \\
138.26) \\
0.24\end{array}$ & $\begin{array}{c}1.35 \\
(0.22- \\
8.62) \\
0.76\end{array}$ & & $\begin{array}{c}0.13 \\
(0.01- \\
1.10) \\
0.15\end{array}$ \\
\hline GEN & $\begin{array}{c}10.74 \\
(0.49- \\
238.92) \\
0.14\end{array}$ & $\begin{array}{c}15.93 \\
(0.74- \\
345.09) \\
0.08\end{array}$ & $\begin{array}{c}1.10 \\
(0.02- \\
60.30) \\
0.97\end{array}$ & $\begin{array}{c}1.95 \\
(0.33- \\
11.76) \\
0.47\end{array}$ & $\begin{array}{c}2.5 \\
(0.20- \\
32.81) \\
0.49\end{array}$ & $\begin{array}{c}0.08 \\
(0.01- \\
1.71) \\
0.11\end{array}$ & $\begin{array}{c}0.86 \\
(0.15- \\
5.0) \\
0.87\end{array}$ & $\begin{array}{c}1.35 \\
(0.22-8.62) \\
0.76\end{array}$ & \\
\hline
\end{tabular}

alues in each cell: Before the parenthesis is odds ratio, within the parenthesis is $95 \% \mathrm{CI}$ and after parenthesis is $\mathrm{p}$ value. $\mathrm{AMP}=$ Ampicillin, $\mathrm{AMX}=$ Amoxicillin, $\mathrm{ERY}=$ Erythromycin, $\mathrm{AZM}=$ Azithromycin, $\mathrm{TET}=\mathrm{Tetracycline}, \mathrm{NA}=\mathrm{Nalidixic}$ acid, $\mathrm{CIP}=$ Ciprofloxacin, LEV=Levofloxacin, $\mathrm{GM}=$ Gentamicin, $\mathrm{CI}=$ Confidence interval

observed in various studies. Moreover, recorded colony characteristics of $E$. coli isolates placed onto EMB agar, MC agar, and SS agar, as well as staining, and biochemical properties were in agreement with the findings of other authors reported elsewhere [32-34].

In our study, the prevalence of Salmonella spp. was found to be $27.5 \%$ (Tables-3 and 4). A study on pigeon diseases at Khulna Sadar and the surrounding private farms was previously conducted [10] and reported $20.32 \%$ salmonellosis, in general, where more cases were detected among younger (30-90 days of age) pigeons. Hosain et al. [9] examined salmonellosis in pigeons from the Mymensingh district and reported $22.22 \%, 58.33 \%$, and $27.50 \%$ prevalence obtained from the cloacal swabs, footpads, and the feces of the pigeons, respectively. However, the overall prevalence of Salmonella spp. was $35.71 \%$. This study also reported a variable prevalence of $40.48 \%, 20.00 \%$, and $30.00 \%$ in markets, farms, and villages, respectively. The prevalence of Salmonella spp. in samples taken from seemingly healthy quails from Mymensingh was reported to be $13.33 \%$ [35]. Furthermore, a study on 400 pigeon samples was conducted in Egypt and reported 5\%, 3.5\%, and 4.6\% prevalence of Salmonella spp. in squabs, pigeon, and environmental samples, respectively [36].

Although most strains of E. coli are harmless and have a common habitat in the digestive tract, some strains can cause diseases, including foodborne illness, in humans. The findings of the present study showed that most of E. coli strains are pathogenic (Table-5). The distribution of pathogenic and non-pathogenic strains is almost similar among the pigeons reared in households and small farms. Tsen et al. [26] reported the primers for the detection of pathogenic and non-pathogenic E. coli. Primer 16E1 is regarded as the forward and the $16 \mathrm{E} 2 / 16 \mathrm{E} 3$ as the reverse primer. PCR products obtained by $16 \mathrm{E} 1+16 \mathrm{E} 2,16 \mathrm{E} 1+16 \mathrm{E} 3$, and $16 \mathrm{E} 1+16 \mathrm{E} 2+16 \mathrm{E} 3$ are of the same 584 bp size. E. coli could not be serotyped in the current study, however, in a separate study conducted by Dutta et al. [37], 150 samples obtained from pigeons were investigated and 
$91 \mathrm{E}$. coli (prevalence $60.67 \%$ ) strains were isolates, where the majority of $E$. coli strains was reported to be pathogenic, including the $\mathrm{O} 157(9.98 \%)$ strain, followed by the O68, O121 (7.69\%), O9, O75, O131 $(5.49 \%), \mathrm{O} 2, \mathrm{O} 13$, and $\mathrm{O} 22(3.30 \%)$ strains. Strains that belonged to serogroup $\mathrm{O} 157$ were reported to be verocytotoxigenic [38]. Hence, it is assumed that E. coli strains circulating in pigeons may cause diarrhea and other illnesses when a potential exposure is created. It is exceedingly difficult to explain the high prevalence of tested bacteria in oral swab samples of healthy pigeons. However, it should be mentioned that pigeons were generally reared in boxes or cages in highly dense areas. The feeder and drinker were placed in the same box. Moreover, the pigeons may have also picked spilled feed from the bedding materials. Therefore, there is a possibility that the droppings of the pigeons were mixed with the feed water and the bedding materials which resulted in the high prevalence of E. coli in the oral swabs as well as in the oral-fecal transmission of bacteria [39-41].

Treatment with one antibiotic may be in association with the development of resistance against another antibiotic due to cross-resistance and co-selection $[42,43]$. Moreover, a given antibiotic may not only contribute to selective resistance against that same antibiotic, the process of which is called "selection," but also to the development of resistance against other antibiotics, a process termed as "co-selection." It is reported that amoxicillin is associated with increased resistance against amoxicillin as well as ciprofloxacin in E. coli [44]. Besides, the frequent use of trimethoprim causes higher levels of resistance to both ciprofloxacin and nitrofurantoin in E. coli. The use of amoxicillin and trimethoprim was also reported to be associated with the development of resistance against ciprofloxacin, possibly due to co-selection [44]. Therefore, it can be concluded that the relationship between antibiotic use and antibiotic resistance is complex [44]. In our study, both positive and negative associations of AMR were identified, although higher frequencies of positive associations were observed in the case of E. coli isolates compared to Salmonella spp. isolates. Furthermore, a strong positive association was found between ampicillin and amoxicillin resistance that may be due to cross-resistance between these two drugs, as reported earlier [42]. Moreover, collateral sensitivity was reported previously in regard of resistance against azithromycin and sensitivity to nalidixic acid among a pathogenic E. coli strain [45]. However, collateral sensitivity could not be observed between these two antibiotics in the current study, which makes it difficult to explain the reason. AMR is a global problem and poses serious public health concerns. One of the major causes of AMR is the indiscriminate use of antibiotics. Bacteria can resist the action of drugs used for different treatments as they produce various enzymes and metabolites that either degrade the antimicrobial agents or help the bacteria survive through various mechanisms. In the present study, nine different antibiotics were used to perform the antibiogram profiling of E. coli and Salmonella spp. isolated from pigeons using the disk diffusion method. Almost all E. coli as well as all Salmonella spp. were found to be resistant to at least one antimicrobial compound used in this study (Table-6), along with a considerable portion of $E$. coli isolates as well as all Salmonella spp. isolates showing MDR traits (Table-7). The fact that MDR strains were found in these birds could be explained by their eating habits. Pigeons can acquire pathogens through food and/or water contaminated with human feces and farm waste. This indicates the possible transmission of E. coli between birds and humans [46]. Our findings are almost similar to the findings reported earlier $[9,47]$. Except for levofloxacin, all the antibiotics are randomly used in pigeons in Bangladesh. The emergence of MDR E. coli with the involvement of co-resistance to three or more different antibiotic classes was reported and reviewed previously [48,49]. Our findings also comply with those prior findings. Keeping this as well as the human-animal-environment interface in mind, our findings suggest that pigeons may contribute to the transfer and spread of microorganisms, as well as antibiotic-resistant bacteria.

\section{Conclusion}

E. coli and Salmonella spp. were isolated and identified from seemingly healthy pigeons, including pathogenic E. coli isolates, with PCR amplification. The overall prevalence of E. coli and Salmonella spp. was $52.5 \%$ and $27.5 \%$, respectively. The antibiogram study revealed a varying degree of resistance to commonly used antibiotics. Besides, it was found that MDR E. coli and Salmonella spp. circulated in seemingly healthy pigeons raised in households and small farms around Dhaka city. Therefore, seemingly healthy pigeons that are reared in households and small farms can host MDR E. coli and Salmonella spp. that may be transmitted to humans as well as other livestock and poultry species.

\section{Authors' Contributions}

SJIK conceptualized the study, did the sample collection, carried out laboratory analysis, data analysis, manuscript preparation, and revision. MI supervised and revised the manuscript. TS, RR, and $\mathrm{JH}$ did the laboratory analysis. JA conceptualized and designed the study, provided diagnostic reagents, supervised, revised the manuscript, and submitted the manuscript. All authors have read and approved the final manuscript.

\section{Acknowledgments}

This work was partially supported by the grant (Serial no-1738, Diary No-962, Year:2017-2018) from the Ministry of Science of Technology (MoST), Government of People's Republic of Bangladesh 
under the National Science and Technology program of MoST and partially by Animal Biotechnology Division (ABD), National Institute of Biotechnology (no grant number). Besides, the authors thank all the owners of the pigeon and staff of ABD, who helped during sample collection and laboratory analysis.

\section{Competing Interests}

The authors declare that they have no competing interests.

\section{Publisher's Note}

Veterinary World remains neutral with regard to jurisdictional claims in published institutional affiliation.

\section{References}

1. Kabir, M.A. (2018) Necessary steps to establish a first-time pigeon farm. J. Dairy Vet. Anim. Res., 7(6): 248-251.

2. Parvez, M.N.H., Islam, M.R., Akter, M.T.D. and Sarder, M.J.U. (2017) Clinico-histopathological observations of pigeons (Columba Livia) suffering from Newcastle disease in Northern Bangladesh. Asian J. Med. Biol. Res., 3(1): 134-139.

3. Alam, M.A., Ali, M.S., Das, N.G. and Rahman, M.M. (2014) Present status of rearing backyard poultry in selected areas of Mymensingh district. Bang. J. Anim. Sci., 43(1): 30-37.

4. Asaduzzaman, M., Mahiuddin, M., Howlider, M.A.R., Hossain, M.M. and Yeasmin, T. (2009) Pigeon farming in Gouripur Upazila of Mymensingh district. Bang. J. Anim. Sci., 38(1-2): 142-150.

5. Kabir, M.A. (2016) Rock-pigeons in some parts of Bangladesh. J. Middle East North Afr. Sci., 2(3): 45-49.

6. Weber, W. (1979) Pigeon associated people diseases. In: Bird Control Seminars Proceedings. University of Nebraska, Lincoln, Nebraska. p21.

7. Tanaka, C., Miyazawa, T., Watarai, M. and Ishiguro, N. (2005) Bacteriological survey of feces from feral pigeons in Japan. J. Vet. Med. Sci., 67(9): 951-953.

8. Lillehaug, A., Monceyron, J.C., Bergsjo, B., Hofshagen, M., Tharaldsen, J., Nesse, L.L. and Handeland, K. (2005) Screening of feral pigeon (Columba livia), mallard (Anas platyrhynchos) and graylag goose (Anser anser) populations for Campylobacter spp., Salmonella spp., avian influenza virus and avian paramyxovirus. Acta. Vet. Scand., 46(4): 193-202.

9. Hosain, M.S., Islam, M.A., Khatun, M.M. and Dey, R.K. (2012) Prevalence and antibiogram profiles of Salmonella spp. Isolated from pigeons in Mymensingh, Bangladesh. Microbes Health, 1(2): 54-57.

10. Paul, T.K., Amin, M.R., Alam, M.A., Rahman, M.K., Sarker, Y.A. and Rizon, M.K. (2015) Occurrence of pigeon diseases at Khulna Sadar, Bangladesh. Bang. J. Vet. Med., 13(2): 21-25.

11. Zinnah, M.A., Haque, M.H., Islam, M.T., Hossain, M.T., Bari, M.R., Babu, S.A.M., Rahman, M.T. and Islam, M.A. (2008) Drug sensitivity pattern of Escherichia Coli isolated from samples of different biological and environmental sources. Bang. J. Vet. Med., 6(1): 13-18.

12. Fallacara, D.M., Monahan, C.M., Morishita, T.Y. and Wack, R.F. (2001) Fecal shedding and antimicrobial susceptibility of selected bacterial pathogens and a survey of intestinal parasites in free living waterfowl. Avian Dis., 45(1): 128-135.

13. Bryan, F.L. and Doyle, M.P. (1995) Health risks and consequences of Salmonella spp. and Campylobacter jejuni in raw poultry. J. Food Prot., 58(3): 326-344.
14. Beutin, L., Geier, D., Steninruck, H., Zimmermann, S. and Scheutz, F. (1993) Prevalence and some properties of verotoxin (Shiga-like toxin) producing Escherichia coli; in seven different species of healthy domestic animals. J. Clin. Microbial., 31(9): 2483-2488.

15. Santaniello, A., Gargiulo, A., Borrelli, L., Dipineto, L., Cuomo, A., Sensale, M., Fontanella, M., Calabria, M., Musella, V., Menna, L.F. and Fioretti, A. (2007) Survey of Shiga toxin-producing Escherichia coli $\mathrm{O} 157: \mathrm{H} 7$ in urban pigeons (Columba livia) in the city of Napoli, Italy. Ital. J. Anim. Sci., 6(3): 313-316.

16. Rodriguez-Siek, K.E., Giddings, C.W., Doetkott, C., Johnson, T.J., Fakhr, M.K. and Nolan, L.K. (2005) Comparison of Escherichia coli isolates implicated in human urinary tract infection and avian colibacillosis. Microbiology (Reading), 151(6): 2097-2110.

17. Ewers, C., Lia, G., Wilking, H., Kießling, S., Alt, K., Antáo, E.M., Laturnus, C., Diehl, I., Glodde, S., Homeier, T., Böhnke, U., Steinrück, H., Philipp, H.C. and Wieler, L.H. (2007) Avian pathogenic, uropathogenic, and newborn meningitis-causing Escherichia coli: How closely related are they? Int. J. Med. Microbiol., 297(3): 163-176.

18. Mora, A., Viso, S., López, C., Alonso, M.P., GarcíaGarrote, F., Dabhi, G., Mamani, R., Herrera, A., Marzoa, J., Blanco, M., Blanco, J.E., Moulin-Schouleur, M., Schouleur, C. and Blanco, J. (2013) Poultry as reservoir for extra intestinal pathogenic Escherichia coli O45:K1:H7B2-ST95 in humans. Vet. Microbiol., 167(3-4): 506-512.

19. Williams, R.J. and Heymann, D.L. (1998) Containment of antibiotic resistance. Science, 279(5354): 1153-1154.

20. Gutiérrez, L.M., Garcia-Lopez, M.L., Otero, A., Garciafernandez, M.C. and Moreno, B. (1990) Incidence of staphylococci in ovine mastitic milk and antibiotic susceptibility of the strains. Milchwissenschaf, 45(12): 778-781.

21. Parry, C.M. and Threlfall, E.J. (2008) Antimicrobial resistance in typhoidal and non typhoidal Salmonella spp. Curr. Opin. Infect. Dis., 21(5): 531-538.

22. Molback, M., Gerrner, S.P. and Wegener, H.C. (2002) Increasing quinolone resistance in Salmonella spp. enterica serotype enteritidis. Emerg. Infect. Dis., 8(5): 514-515.

23. Threlfall, E.J. (2002) Antimicrobial drug resistance in Salmonella spp.: Problems and perspectives in food and waterborne infections. FEMS Microbiol. Rev., 26(2): 141-148.

24. Merchant, I.A. and Packer, R.A. (1967) Veterinary Bacteriology and Virology. $7^{\text {th }}$ ed. The Iowa University Press, Ames, Iowa, USA. p286-306.

25. Cowan, S.T. (1985) Cowan and Steel's Manual for Identification of Medical Bacteria. $2^{\text {nd }}$ ed. Cambridge University Press, Cambridge. p138-139.

26. Tsen, H.Y., Lin, C.K. and Chi, W.R. (1998) Development and use of 16S rRNA gene targeted PCR primers for the identification of Escherichia coli cells in water. J. Appl. Microbiol., 85(3): 554-560.

27. Bauer, A.W., Kirby, W.M.M., Sherris, J.C. and Truck, M. (1966) Antibiotic susceptibility testing by a standardized single disk method. Am. J. Clin. Pathol., 45(4): 493-496.

28. CLSI. (2017) Performance Standards for Antimicrobial Susceptibility Testing. 27 $7^{\text {th }}$ ed. Clinical and Laboratory Standards Institute, Wayne, Pennsylvania, USA.

29. Magiorakos, A.P., Srinivasan, A., Carey, R.B., Carmeli, Y., Falagas, M.E., Giske, C.G., Harbarth, S., Hindler, J.F., Kahlmeter, G., Olsson-Liljequist, B., Paterson, D.L., Rice, L.B., Stelling, J., Struelens, M.J., Vatopoulos, A., Weber, J.T. and Monnet, D.L. (2012) Multidrug-resistant, extensively drug-resistant and pandrug-resistant Bacteria: An international expert proposal for interim standard definitions for acquired resistance. Clin. Microbiolo. Infect., 18(3): 268-281.

30. Islam, M.R., Biswas, P.K. and Ali, M.L. (2004) Diseases of pigeons reared on small-holdings in Bangladesh. Int. J. Adv. Vet. Sci. Tech., 3(1): 119-130.

31. Dey, R.K., Khatun, M.M., Islam, M.A. and Hosain, M.S. 
(2013) Prevalence of multidrug-resistant Escherichia coli in pigeon in Mymensingh, Bangladesh. Microbes Health, 2(1): 5-7.

32. Buxton, A. and Fraser, G. (1997) Escherichia coli. In: Animal Microbiology. Vol 1. Blackwell Scientific Publications, Oxford, London, Edinburg, Melbourne. p7880.

33. Freeman, B.A. (1985) Burrows Textbook of Microbiology. $22^{\text {nd }}$ ed. W. B. Saunders Company, Philadelphia, London, Toronto. p464-475.

34. Jones, T.O. (1987) Intramammary antibiotic preparations and cephalosporin resistance in Salmonella Typhimurium 204c. Vet. Record, 120(16): 399-400.

35. Jahan, S., Zihadi, M.A.H., Nazir, K.H.M., Islam, M.S., Rahman, M.B. and Rahman, M. (2108) Molecular detection and antibiogram of Salmonella spp. from apparently healthy Japanese quails of three different quail farms in Mymensingh. J. Adv. Vet. Anim. Res., 5(1): 60-66.

36. Ammar, A., Sultan, H., El-Sayed, I., Yousef, S. and Mamdouh, R. (2014) Seroprevalence of salmonellosis among pigeon and its surrounding environment and isolation of Salmonella spp. Species. Int. J. Sci. Res., 3(9): $1857-1862$.

37. Dutta, P., Borah, M.K., Sarmah, R. and Gangil, R. (2013) Isolation, histopathology and antibiogram of Escherichia coli from pigeons (Columba livia). Vet. World, 6(2): 91-94.

38. Oboegbulem, S.I., Abiade, C.U., Onunkwo, J.I., Ezenduka, E.V., Chah, F.K., Nwanta, J.A. and Anosike, C.T. (2009) Incidence of verotoxigenic Escherichia coli in poultry in Nsukka urban area of Southeastern Nigeria. Anim. Sci. Report., 3(4): 128-131.

39. Alexander, J., Wilson, G.W., Russel, P.H., Lister, S.A. and Parsons, G. (1985) Newcastle disease outbreaks in fowl in Great Britain during 1984. Vet. Rec., 117(17): 429-434.

40. Ritchie, B.W. and Carter, K. (1995) Avian Viruses: Function and Control. Publishing Incorporated, Lake Worth, Florida. p285-311.

41. Catroxo, M.H.B., Martins, A.M.C., Petrella, S., Curi, N.A. and Melo, N.A. (2011) Research of viral agent in free-living pigeon feces (Columba livia) in the city of São Paulo, SP,
Brazil, for transmission electron microscopy. Int. J. Morphol., 29(2): 628-635.

42. Pouwels, K.B., Freeman, R., Muller-Pebody, B., Rooney, G., Henderson, K.L., Robotham, J.V. and Smieszek, T. (2018) Association between use of different antibiotics and trimethoprim resistance: Going beyond the obvious crude association. J. Antimicrob. Chemother., 73(6): 1700-1707.

43. Kahlmeter, G. and Menday, P. (2003) Cross-resistance and associated resistance in $2478 \mathrm{E}$. coli isolates from the PanEuropean ECO. SENS Project surveying the antimicrobial susceptibility of pathogens from uncomplicated urinary tract infections. J. Antimicrob. Chemother., 52(1): 128-131.

44. Pouwels, K.B., Muller-Pebody, B., Smieszek, T., Hopkins, S. and Robotham, J.V. (2019) Selection and co-selection of antibiotic resistances among Escherichia coli by antibiotic use in primary care: An ecological analysis. PLoS One, 14(6): e0218134.

45. Imamovic, L. and Sommer, M.O.A. (2013) Use of collateral sensitivity networks to design drug cycling protocols that avoid resistance development. Sci. Transl. Med., 5(204): 204ra132.

46. Borges, C.A., Cardozo, M.V., Beraldo, L.G., Oliveira, E.S., Maluta, R.P., Barboza, K.B., Werther, K. and Avila, F.A. (2017) Wild birds and urban pigeons as reservoirs for diarrheagenic Escherichia coli with zoonotic potential. J. Microbiol., 55(5): 344-348.

47. Saifullah, M.K., Mamun, M.M., Rubayet, R.M., Nazir, K.H.M., Zesmin, K. and Rahman, M.T. (2016) Molecular detection of Salmonella spp. Isolated from apparently healthy pigeon in Mymensingh, Bangladesh and their antibiotic resistance pattern. J. Adv. Vet. Anim. Res., 3(1): 51-55.

48. Akond, M.A., Shirin, M., Alam, S., Hassan, S.M.R., Rahman, M.M. and Hoq, M. (2012) Frequency of drug resistant Salmonella spp. Isolated from poultry samples in Bangladesh. Stamford J. Microbiol., 2(1): 15-19.

49. Ahmed, I., Rabbi, M.B. and Sultana, S. (2019) Antibiotic resistance in Bangladesh: A systematic review. Int. J. Infect. Dis., 80: 54-61. 